\title{
Çalışma Yaşamında Siber Mağduriyet ve Siber Zorbalığa İlişkin Duyarlılığın Özsaygıya Etkisi
}

\author{
DOI: $10.26466 /$ opus.724131
}

\author{
* \\ Çiğdem Çakır* - Esra Gökçen Kaygısız ** \\ *Dr., Kadriye Abdülmecit Özgözen Ortaokulu, Gaziantep \\ E-Posta: cigdemcakir1905@gmail.com \\ ORCID: 0000-0003-1954-5214 \\ ** Dr. Öğr. Üyesi, Giresun Üniversitesi, İktisadi ve İdari Bilimler Fakültesi, Giresun \\ E-Posta: esgokk@hotmail.com \\ ORCID: $\underline{0000-0002-4950-9508}$
}

\begin{abstract}
Öz
Günümüzde teknolojinin çok büyük kitleler tarafindan kullanılması ile zorbalık, yöntem ve araç değiştirmiş ve siber zorbalık adını almıştır. Siber zorbalık, bilgi ve iletişim teknolojileri kullanarak hedef olarak belirlenen kişi veya kişileri incitmeye, tehdit etmeye, aşağılamaya, dışlamaya, ayrım yapmaya yönelik davranışlardır. Siber zorbalık, mağdurlar üzerinde çeşitli olumsuzluklara neden olmaktadır. Bu olumsuzluklara genel olarak siber mağduriyet denilmektedir. Siber mağduriyet ise mağdurlarm özsaygılarını azaltmaktadır. Araştırma bu doğrultuda çalışanların siber mă̆duriyet ve siber zorbalı̆̆a ilişkin duyarlılık düzeylerini ve duyarlılıklarının özsaygılarına olan etkisini belirlemeyi amaçlamıştır. Çalışmanın örneklemi, Gaziantep ili merkez Şahinbey ilçesi sınırlarındaki resmi okullarda görev yapan ilk ve ortaokul yöneticileri ve öğretmenler oluşmaktadır. Araştırmada değerlendirilecek verileri toplanmak içina Kişisel Bilgi Formu, Yenilenmiş Siber Zorbalık Envanteri, Siber Zorbalığa İlişkin Duyarlılık Ölçeği ve Rosenberg Benlik Değeri Ölçeği kullanılmıştır. Verilerin analizinde betimsel istatistiklerden ve hiyerarşik çoklu regresyon analizinden faydalanılmıştır. Elde edilen bulgular doğrultusunda siber mağduriyet yaşayan okul yöneticileri ve öğretmenlerin özsaygı düzeyleri ile siber zorbalı$\breve{g}$ a ilişkin duyarlılık düzeyleri arasında orta düzeyde, pozitif ve anlaml bir ilişki olduğu sonucuna varılmıştır.
\end{abstract}

Anahtar Kelimeler: Siber zorbalık, Özsaygı, Siber mağduriyet 


\title{
The Effect of Cyber Victimization and Cyberbullying Sensitivity on Self-Esteem in Work Life
}

\begin{abstract}
Today, bullying has changed methods and tools with the use of technology by very large masses and named as cyberbullying. Cyberbullying is behaviours aimed at hurting, threatening, humiliating, excluding and discriminating the person or persons identified as targets using information and communication technologies. Cyberbullying causes various negativities on victims. Generally, these negativities are called cyber victimization. Cyber victimization reduces victims' self-esteem. Accordingly, the study aimed to determine the cyber victimization and cyberbullying sensitivity levels of employees and the effect of their sensitivity on their self-esteem. The sample of the study consists of school administrators and teachers that are working at official schools that are at Gaziantep province, Shahinbey district. In order to collect data, Personal Information Form, Revised Cyber Bullying Inventory, Cyberbullying Sensitivity Scale and Rosenberg Self-Esteem Scale were used. Descriptive statistics and hierarchical multiple regression analysis were used to analyse the data. In line with the findings obtained, it is concluded that there is a moderate, positive and meaningful relationship between the selfesteem levels and sensitivity to cyberbullying level of school administrators and teachers who experienced cyber victimization.
\end{abstract}

Keywords: Cyberbullying, Self-esteem, Cyber victimization 


\section{Giriş}

Bilindiği gibi internet birçok bakımdan sosyal, politik, kültürel yaşamda hayati bir rol oynarken bireylerin kimliklerini oluşturmaları, başkalarıyla iletişim kurmaları, fikir ve endişeleri paylaşmaları için de bir alan sağlamaktadır (Papacharissi, 2002'den Akt. Lumsden ve Harmer, 2019, s. 2; Turkle, 1995). İnternetin bu özellikleri bireylere denetimsiz, kesintisiz ve özgür iletişim ortamları sunmakta ve hayatın birçok olgusunu sanallaştırmaktadır. Her geçen gün çeşitlenen ve değişen bu iletişim ortamları ise fiziksel ve psikolojik şiddet unsurlarını da sanal ortama taşımaktadır. internetin getirdiği en büyük olumsuzluklardan birisi olan siber zorbalık, kimi zaman siber tartaklama, sanal zorbalık, elektronik şiddet, siber taciz, sanal taciz, çevrim içi şiddet ya da dijital şiddet olarak da adlandırılmaktadır. Dolayısıyla siber zorbalık, şiddet içeren davranışların elektronik donanım ve yazılımlar aracılığıyla yapılan şekli olarak tanımlanabilir. Diğer bir deyişle teknolojinin yaygınlaşmasıyla ortaya çıkmış olup zorbalığın dijital halidir. Siber zorbalık, failin bilgi ve iletişim teknolojilerini kullanarak her gün ve günün her anında hedefe yönelik zorbalık yapmasına olanak vermektedir. Siber zorbalık gündelik yaşamda, iş ve eğitim yaşamında her yaş grubunda ve her özellikteki bireyi tehdit eden bir olgudur. Bu nedenle 21. yüzyılın yeni zorbalık biçimi olarak kabul edilebilir. Siber zorbalık, zorbanın istediği yer, zaman ve mekânda ve istediği sıklıkta mağdura yönelik zorbalık davranışları sergilemesine olanak veren bir şiddet türüdür. Ayrıca mağduru rahatsız edici, aşağılayıcı, onur zedeleyici, kırıcı, taciz edici ve benzeri içeriklerin saniyeler içinde dünya çapında milyonlarca kişi tarafından görülmesine, kopyalanmasına, saklanmasına ve yıllar sonra tekrar paylaşılmasına neden olmaktadır. Zorba tüm bu eylemleri cep telefonu, tablet ve bilgisayarlar aracılığıyla internet üzerinden web siteleri, bloglar, sosyal medya uygulamaları, oyunlar, forumlar, e-posta hesapları aracılığıyla yapmaktadır.

Siber zorbalık bir başka taraftan siber mağduriyeti yaratmaktadır. Siber mağduriyet, siber zorbalığa davranışlarıyla karşı karşıya kalınması ve bu davranışlardan somut ya da soyut olarak bireyin zarar görmesi durumudur. Siber zorbalık en başta mağduru olumsuz etkilemektedir. Bazı durumlarda mağdurla birlikte ailesini, yakın çevresini veya çalıştı̆̆ kurumu da maddi ya da manevi olarak etkilemektedir. Ayrıca bu durumun mağdurlar üze- 
rinde farklı olumsuz etkileri vardır. Bu çalı̧̧mada siber mağduriyetin bireylerin özsaygıları üzerindeki etkisi araştırılmaktadır.

Çalışma diğer hizmet sektörlerine göre iletişimin daha yoğun ve önemli olduğu eğitim sektöründe yapılmıştır. Diğer sektör çalışanları sadece müşteri veya danışanlarına karşı sorumlu olup doğrudan onlarla iletişim halinde iken özellikle öğretmenler ve yöneticiler öğrenci ya da ebeveynlerle de sürekli iletişim halinde olmak durumundadırlar. Bilgi ve iletişim teknolojilerinin yaygınlaşmasıyla öğretmenler, mesai saatleri dışında veliler tarafından sıklıkla telefonla, sosyal medya kanallarıyla ya da çevrim içi mesajlaşma programlarıyla aranmaktadırlar. Bu durum öğretmenlerin iş-özel hayat dengesini bozmakta, iletişim bilgilerinin, kişisel numaralarının ve sosyal medya hesap bilgilerinin izinsiz paylaşımına neden olmaktadır. Dolayısıyla öğretmenlerin öğrenci, veli ve çalışma arkadaşları tarafından siber mağduriyete uğrama riskleri diğer sektörlere göre daha fazladır. Ayrıca öğretmenlerin öğrencilerine olan sorumlulukları onların siber zorbalık ve siber mağduriyete ilişkin duyarlılıklarının yüksek olmasını gerektirmektedir. Bu noktadan hareketle mevcut çalışmada, ilk ve orta dereceli okullarda görev yapan öğretmen ve yöneticilerin siber mağduriyet ve siber zorbalığa ilişkin duyarlılık düzeylerini ve duyarlılıklarının özsaygılarına etkisini belirlemek amaçlanmıştır.

\section{Siber Zorbalık ve Siber Mağduriyet}

Bilinen zorbalıktaki fiziksel mekân ve zamanın dışına çıkmış hali olan siber zorbalık, maalesef çağımızın artan zorbalık biçimidir. Fiziksel zorbalıkta zorba ile mağdurun aynı ortamda bulunmaları gerekirken siber zorbalıkta bu koşul gerekli değildir. Yani siber zorbalık coğrafya, mekân ve zamandan bağımsız olarak her zaman, her yerden yapılabilmektedir. Bir başka ifadeyle her zaman siber zorbalığa maruz kalınma ihtimali bulunmaktadır. Siber zorbalıkta mağdurlar internet, cep telefonu kullanmamaları dahi sanal ortamda kendilerine yönelik saldırıları engellemekte yeterli olamamaktadır. Bu nedenle siber zorbalık sıradan bir şiddet vakasından ve yüz yüze akran zorbalığından daha tehlikelidir (Akça ve Sayımer, 2017, s. 3).

Smith ve arkadaşlarına göre (2008, s. 366) siber zorbalık, bir grup veya bireyin elektronik iletişim formların kullanarak, kendisini kolayca savunamayan bir mağdura karşı defalarca yürüttüğü saldırgan ve kasıtlı bir ey- 
lemdir. Farley ve arkadaşlarına göre (2015, s. 437) siber zorbalık herhangi bir zamanda ortaya çıabilen, faillerin anonim kalabildiği ve siber eylemlerle süren şiddet türüdür. ABD Ulusal Suç Önleme Konseyi'ne göre siber zorbalık, başka bir kişiyi incitmek ya da utandırmak için yapılan internet, mobil telefonlar ve diğer cihazlarla yazılı metin ya da resim göndermektir (Makri-Botsari ve Karagianni, 2014, s. 3242). Siber zorbalık, mağdurun doğrudan cep telefonundan aranması veya onun resim ve fotoğraflarının paylaşılması (Demirtaş ve Karaca, 2018, s. 24), mağdurun cinsel içerikli görüntülerini çekip bunları internet ortamında yayınlanması, başkası gibi davranması, tehdit edilmesi (Özmen, 2018, s. 959) gibi birçok davranış şeklini içermektedir. Ayrıca mağdura ait olan bir görüntünün üzerinde değişiklik yapılması ya da başka birine ait olan görüntüye mağdurun yüzünün eklenmesi veya mağdur ile ilgili doğru olmayan bilginin paylaşılması; mağdur ile ilgili özel bilgilerin ifşa edilmesi; mağdurun özel bilgilerini, sırlarını paylaşması için kandırılması; arkadaşlık listelerinden ve çevrimiçi sohbet gruplarından çıkarılması, mağdurun tüm hesaplarının, listesindeki kişilerin sürekli takip edilmesi gibi davranışlar da siber zorbalık davranışlarıdır. Özet olarak siber zorbalığın teknoloji ile alakalı her ortamda sıklıkla karşılaşılabilen, diğer şiddet türleri kadar bireye zarar veren ve önemli problemlere neden olabilen bir şiddet türüdür (Cebecioğlu ve Altıparmak, 2017, s. 425).

Siber zorbalık tıpkı fiziksel şiddet olgusundaki gibi birçok farklı nedene dayanmaktadır. Bunlar genellikle bireysel, örgütsel ve sanal ortamdan kaynaklı olmak üzere üç temel başlıkta ele alınmaktadır (Kaygısız, 2020, s. 108):

1. Bireysel Nedenler: Zorbanın kişisel özellikleri; intikam alma, rahatsızlık verme, tehdit etme amacl; eğlenme, dalga geçme ihtiyacl; teknolojik yetenek ve yatkınlıklarını öne çıkarma isteği; mağdura yapmak istemediği bir şeyi yaptırmak ya da zorbanın çıarları doğrultusunda karar vermesini, eyleme geçmesini sağlamatır.

2. Örgütsel Nedenler: Bilgi güvenlik politikalarındaki eksiklikler ve bu politikalara uyulmaması, iş ve özel hayat dengesinin bozulması, kişisel bilgi güvenliği ve mahremiyetini korumaya önem verilmemesi, kaba ve zorba davranışlara müsamaha gösterilmesi ve tüm bu davranışları besleyen bir örgüt kültürünün olmasıdır.

3. Sanal Ortamdan Kaynaklı Nedenler: Tehditkâr ve aşağılayıcı fotoğraf, video, ses ve metin gibi içeriklerin kısa sürede çok sayıda kişiye ulaştırı- 
labilmesi; bunların internet sitelerinde ya da sosyal paylaşım sitelerinde başka kişilerin erişimine açılmasına, üzerinde ekleme-çıkarma yapılmasına, çoğaltılmasına ve uzun süre saklanmasına olanak vermesi; mağdur ile yüz yüze iletişim kurulmaması, dolayısıyla zorbanın bu davranışının sorumluluğunu üstlenmemesi; zaman ve mekândan bağımsızlık; kimliğini gizleyebilme; sanal alanın yeterince denetlenmemesi, çoğu zaman zorbanın bulunamaması, yasal süreçlerdeki eksikliklerdir.

Tüm zorbalık davranışlarında olduğu gibi siber zorbalık davranışlarında da belirli kasıtlar bulunmaktadır. Zorbanın amacı, hedef olarak belirlediği kişi veya kişileri teknoloji aracılığyyla incitmek, hedef göstermek, tehdit etmek, aşağılamak, dışlamak ve takip etmektir. Dolayısıyla siber zorbalık davranışlarına maruz kalan mağdurlar fiziksel zorbalık davranışlarının aksine psikolojik olarak zarar görmektedirler. Ayrıca siber zorbanın kimliğini gizlemesi, çoğu zaman kim olduğunun tespit edilememesi mağdur üzerindeki olumsuz etkileri artırmaktadır. Bu yönüyle de siber zorbalığın çağın en önemli psikolojik tehditlerinden birisi olduğu söylenebilir. Siber zorbalık, herkesi ilgilendiren ve gerekli tedbirlerin alınması gereken acil bir konudur. Çünkü siber zorbalığın yarattığı sorunlar dünyada birçok çocuğun, ergenin ve yetişkinin hayatını etkilemektedir (Charoenwanit, 2019, s. 232).

Siber zorbalık davranışlarına maruz kalan kişilerde oluşan tüm bu psikolojik ve sonrasında ortaya çıkan fiziksel zararlar siber mağduriyet kapsamında değerlendirilmektedir. Siber mağduriyet, bilgi ve iletişim teknolojilerini kullanarak birey, grup, özel ya da tüzel bir kişiliğe karşı yapılan teknik ya da ilişkisel tarzda zarar verici davranışlarla karşı karşıya kalınması ve bu davranışlar sonucunda maddi ya da manevi olarak mağduriyet yaşanmasıdır (Arıcak, Tanrıkulu ve Kınay, 2012, s. 2). Bir başka tanıma göre kavram, iletişim teknolojileri aracilığıyla kişisel mahremiyetin ihlali, kişisel verilerin istismarı, kişilerin özel alanına ve iletişim alanına girilmek sureti ile yapılmış etik dışı davranışlardır (Çiftçi, 2019, s. 1539). Siber mağduriyet, siber zorbalığa uğrayan kişi veya kişilerin yaşadığı tüm duygusal, sosyal ve psikolojik olumsuzlukların toplamı olarak tanımlanabilir.

Siber mağduriyette mağdurların devamsızlık, kaytarma, başarıda düşme gibi mesleki ve akademik problemler; sıkıntı, kaygı, yalnızlık, depresyon, güvensizlik, özsaygıda azalma ve intihar eğilimi gibi duygusal problemler 
ve saldırganlık, şiddet, madde bağımlılığı gibi davranış problemleri yaşadıkları belirtilmektedir (Charoenwanit, 2019, s. 232). Bu kişilerde sosyal iletişim kuramama, arkadaş ortamına uyum sağlayamama, benlik algısının azalması, dışlanmışlık, çaresizlik, korku, mutsuzluk, üzüntü, agresyon, depresyon, kızgınlık, kaygı, aile ve arkadaşlar arası problemler, hayal kırıklı̆ıı, savunmasızlık ve öz saygıda düşüş gibi psikolojik problemler görülmektedir (Hinduja ve Patchin, 2006'dan Akt. Bridge ve Duman, 2019, s. 159). Sosyal ve duygusal problemler yaşayan, yalnız, arkadaşlık ilişkilerinde mutlu olamayan, arkadaş sayısı az ve özsaygısı düşük olan kişilerin daha fazla siber mağduriyet yaşadıkların belirtilmektedir (Campfield, 2008, s. 18). Şahin (2012, s. 836) ise siber zorbalık ile yalnızlık arasında ilişki olmamasına rağmen siber mağduriyet ile yalnızlığın ilişkili olduğunu vurgulamaktadır. Ayrıca siber ortamda mağdura yapılan genel zorbalığa tanık olanların sayıca fazla olması, zorbalık sürecinde kullanılan materyallerin veya ekran görüntülerinin paylaşılmaya devam ettirilmesi ile siber mağduriyetin yayılması, zorbanın çoğu zaman anonim kalabilmesi ve zorbalığın etkilerini birebir gözlemlemediği için fiziksel zorbalıktan daha kötü sonuçlar doğurabilecek hareketleri daha kolaylıkla yapabilmesi sanal ortamdaki mağdurların yaşadığı zorbalığın daha olumsuz sonuçlar doğurmasına ve etkilerinin daha ağır olmasına neden olabilmektedir (Aslan ve Önay Doğan 2017, s. 103). Bu bağlamda siber zorbalığın türü, süresi, yayılım hızı ve etkisi ile mağdurun kişisel özellikleri ve duyarlılığının siber mağduriyetin olumsuzluklarını ve maruz kalma düzeyini etkilediği söylenebilir.

\section{Özsayg1}

Benlik saygısı olarak da ifade edilen özsaygı kavramı, bireyin kendisine dair benimsediği olumlu duygulardır. Kavram, Türk Dil Kurumu ${ }^{1}$ tarafından "İnsanın kendine duyduğu sayg1, onur, haysiyet, izzetinefis" olarak tanımlanmaktadır. Özsayg1, kişinin kendine güvenmesi ve kendine inanmasını içeren bir yeterlilik duygusunu ifade etmektedir (Uğur vd., 2763, s. 2019). Özsayg1, kişinin kendi kendini değerlendirmesi sonucunda ulaştı̆̆ benlik kavramını onaylamasından doğan beğeni ve kabul durumu olup bu beğenme sonucunda birey kendini değerli, olumlu, beğenilmeye ve sevilmeye değer bulması sürecidir (Yılmaz, 2011, s. 51). Bir başka ifadeyle özsaygı,

\footnotetext{
${ }^{1}$ Türk Dil Kurumu, www.tdk.gov.tr
} 
kişinin kendi kişiliğine karşı verdiği saygının ve değerin derecesidir. Öyleyse kişi kendine ne kadar fazla saygı duyuyor ve değer veriyorsa özsaygıs1nın da o kadar yüksek olduğu söylenebilir.

Özsayg1, başkalarının saygısı, yeterlik hissi ve kişinin bu iki kaynağı kendisi için değerlendirmesine (kendilik) bağlıdır (Özkan, 1994, s. 5). Bununla birlikte özsaygı, birçok davranışının hem nedeni hem de sonucu olarak değerlendirilmelidir (Rosenberg vd., 1995, s. 144). Örneğin özsaygısı yüksek kişiler kibar, cömert, kendi kendilerini kontrol eden, başarıll, sevimli, arkadaş çevresi içinde popüler, yetenekli, çekici, anlayışlı ve kendine güvenen kişilerdir (Furnham, 2008, s. 212-213). Bu kişiler kendilerine karşı hissettikleri özgüven ile hayattaki tüm zorluklarla baş edebileceklerine özsaygisı düşük olan kişilere göre daha fazla inanmakta ve başarılı olma eğilimi göstermektedirler (Doğan vd., 2016, s. 788). Özsaygısı düşük olan bireylerde ise bu duygu ve davranışların düşük olduğu ve bireylerin birçok olumsuz davranışlar sergiledikleri bilinmektedir. Bunlardan birisi de şiddet davranışlarıdır. Özsaygısı yüksek olan birey kendini olumlu olarak değerlendirip saldırgan tutumlardan uzak dururken (Reisoğlu vd., 2013, s. 153), özsaygısı düşük bireyler daha fazla şiddet davranışı sergilemektedirler (Şahin Baltacı ve Altan, 2016, s. 234). Bu doğrultuda siber zorbalık davranışı sergileyen kişilerin de özsaygılarının düşük olabileceği ve mağdurlarda yarattıkları siber mağduriyetin de özsaygıda azalmaya neden olacağı söylenebilir. Patchin ve Hinduja (2010, s. 614) tarafından yapılan çalışmada demografik özelliklerden bağımsız olarak düşük özsaygının siber zorbalık ve siber mağduriyet ile ilişkilendirildiği belirtilmektedir. Healy (2013, s. 39) yaptı̆̆ı çalışmada siber mağduriyet yaşayanların yaşamayanlara göre özsaygiların biraz daha düşük olduğunu bulmuştur. Taştekin'in (2015, s. 85) çalışması düşük özsaygının siber zorbalıktaki ve siber mağduriyetteki artışı açıkladığını ve bireyin özsaygısı arttıkça siber zorbalığın ve mağduriyetin azaldığını göstermektedir. Bir başka çalışmada ise özsaygı puanındaki azalma, siber mağduriyetteki artışı anlamlı düzeyde açılamakta ve düşük özsaygısı ile siber mağduriyet arasında ilişki olduğunu göstermektedir (Pekşen Süslü, 2016, s. 109). Aliyev ve Gengec (2019, s. 161) ise çalışmalarında özsayg ile siber zorbalık arasında negatif ve ters yönlü ilişki olduğu sonucuna varmışlardır.

Zorbalığın özsaygı üzerinde yarattığı etki mağdurun duyarlılı̆̆ 1 ile de ilişkilidir. Duyarlı mağdurlar sürekli çevrelerini gözden geçirerek olası yeni 
tehlikelere karşı çok dafa fazla uyanık olmaya, olası tehdit unsurlarını tanımaya çalışır ve bunların kendilerini incitmesine imkan vermemek için tepki gösterirler (Bayezid, 2000, s. 100). Tanrıkulu, Kınay ve Arıcak'a (2013, s. 40) göre duyarlılı̆̆ yüksek olan bu bireylerin duygusal tehditlere karşı uyarılma eşikleri daha düşüktür. Böylelikle bu bireyler, siber zorbalığa karşı farkındalıklarını artırarak tehditler başlamadan önlem almakta ya da siber zorbalığı hemen fark etmektedirler. Bir başka ifadeyle bireylerin siber zorbalık hakkında bilgi sahibi olmaları ve siber zorbalığa ilişkin duyarlılık oluşturmaları, kendilerini siber zorbalıktan korumaları ve siber zorbalık davranışlar sergilememeleri için önemli bir adımdır (Baştak ve Altınova, 2015, s. 100). Bunun tam tersi durumda duyarlılığın düşük olması siber mağduriyet ve siber zorbalığı artırmaktadır. Ayrıca duyarlılığı düşük olanların siber zorbalık ve siber mağduriyete daha fazla taraf oldukları ve bu kişilerin düşük özsaygı düzeyine sahip oldukları bilinmektedir (Brack ve Caltabiano, 2014, s. 2). Bu bağlamda siber zorbalık ya da mağduriyete ilişkin duyarlılığın özsaygı üzerinde etkili olacağı söylenebilir.

\section{Yöntem}

Bu bölümde araştırma modeli, evren ve örneklem, veri toplama araçları, verilerin toplanması ve analiz süreci belirtilmektedir.

\section{Araştırma Modeli}

Araştırmada ilişkisel tarama modeli kullanılmıştır. İlişkisel tarama modeli, iki ya da daha çok değişken arasında birlikte değişim varlığını belirlemeyi amaçlayan tarama modelidir (Karasar, 2012, s. 83). Siber zorbalığa ilişkin duyarlılık düzeyleri ve özsaygı arasındaki ilişki, kamuya bağlı ilk ve orta dereceli okullarda görev yapan yönetici ve öğretmenlere uygulanan ölçeklerle belirlenmeye çalışılmıştır. Bu çerçevede; (i) örneklem grubunun siber mağduriyet durumu belirlenmiş, (ii) siber mağdurlarda siber zorbalığa ilişkin duyarlılığın özsaygıya etkisi incelenmiştir.

\section{Evren ve Örneklem}

Araştırma evrenini Gaziantep ili merkez ilçelerinden Şahinbey'de, T.C. Milli Eğitim Bakanlığı'na bağlı resmi okullarda görev yapan okul yöneticileri ve öğretmenler oluşturmaktadır. Örneklem seçiminde oransız küme örnekle- 
me yöntemi kullanılmıştır. Şahinbey'deki her okul bir küme olarak kabul edilmiş ve oransız küme örnekleme yöntemi ile belirlenen okullarda görev yapan 500 yönetici ve öğretmene ulaşılmıştır. Kişisel bilgi formunun ve ölçeklerin bulunduğu 445 form katılımclar tarafından doldurulmuş ve 352 katılımcıdan elde edilen veriler analize alınmıştır. Örnekleme ilişkin demografik bilgiler Tablo 1'de verilmiştir.

Tablo 1. Araştırmanın örneklemine ilişkin demografik bilgiler

\begin{tabular}{|c|c|c|c|}
\hline Değişken & Grup & $\mathrm{N}$ & $\%$ \\
\hline \multirow{3}{*}{ Cinsiyet } & Kadın & 206 & 58,5 \\
\hline & Erkek & 146 & 41,5 \\
\hline & Toplam & 352 & 100 \\
\hline \multirow{4}{*}{ Yaş } & 42 ve üstü & 29 & 8,2 \\
\hline & 41-32 arası & 170 & 48,3 \\
\hline & 31 ve altı & 153 & 43,5 \\
\hline & Toplam & 352 & 100 \\
\hline \multirow{3}{*}{ Öğrenim düzeyi } & Lisans & 312 & 88,6 \\
\hline & Lisansüstü & 40 & 11,4 \\
\hline & Toplam & 352 & 100 \\
\hline \multirow{4}{*}{ Kidem } & $1-5$ yil & 88 & 25,0 \\
\hline & $6-10$ yil & 94 & 26,7 \\
\hline & 11 yıl ve üzeri & 170 & 48,3 \\
\hline & Toplam & 352 & 100 \\
\hline \multirow{3}{*}{ Siber mağduriyet } & Mağdur & 99 & 28,1 \\
\hline & Mağdur olmayan & 253 & 71,9 \\
\hline & Toplam & 352 & 100 \\
\hline
\end{tabular}

Tablo 1' de görüldüğü gibi, araştırmaya katılan 352 okul yöneticisi ve öğretmenin \% 41,5'i ( $n=146)$ erkek, \% 58,5'i $(n=206)$ kadındır. Örneklem grubunun \% 8,2'si $(n=29) 42$ yaş ve üstü, \% 48,3'ü $(n=170) 41-32$ arasında, \% $43,5^{\prime} \mathrm{i}(n=153) 31$ yaş ve altındadır. Yönetici ve öğretmenlerin $\% 88,6$ 's1 ( $n=$ 312) lisans ve \% 11,4'ü $(n=40)$ lisansüstü öğrenimi görmüş, \% 25'i $(n=88)$ 1-5 yıl, \% 26,7'si (n= 94) 6-10 yıl, \% 48,3'ü $(n=170)$ ise 11 yıl ve üzeri mesleki kıdeme sahiptir. Ayrıca araştırmaya katılan yönetici ve öğretmenlerin \% $28,1^{\prime} \mathrm{i}(n=99)$ siber mağdur, \% 71,9'u $(n=253)$ ise siber mağdur olmayan grubundadir.

\section{Veri Toplama Araçları}

Araştırmada verilerin toplanması amacıyla demografik değişkenleri içeren "Kişisel Bilgi Formu", Topçu ve Erdur-Baker (2010) tarafından geliştirilmiş 
Tanrıkulu (2015) tarafından düzenlenmiş olan "Yenilenmiş Siber Zorbalık Envanteri", Tanrıkulu, Kınay ve Arıcak (2013) tarafından geliştirilen "Siber Zorbalığa İlişkin Duyarlılık Ölçeği", Rosenberg (1965) tarafından geliştirilmiş Çuhadaroğlu (1986) tarafindan Türkçe'ye uyarlanan "Rosenberg Benlik Değeri Ölçeği" kullanılmıştır.

Yenilenmiş Siber Zorbalık Envanteri (YSZE): Envanter Topçu ve ErdurBaker (2010) tarafından uyarlanmış Tanrıkulu (2015) tarafından yenilenmiştir. Envanter, katılımcıların siber zorbalık yapma ve siber zorbalığa uğrama deneyimlerini iki bölümde ölçmektedir. İki bölümü de aynı maddelerden oluşan envanterin ilk bölümü siber zorbalık yapma, ikinci bölümü ise siber zorbalığa uğrama deneyimlerini ölçmektedir. Katılımclardan maddelere, son altı ayda siber zorbalık yaptılarsa ilk kısımda "Ben yaptım" son altı ayda siber zorbalığa uğradılarsa ikinci kısımda "Bana yapıldı" diye düşünerek cevap vermeleri istenmektedir. Envanter dörtlü derecelendirme ile " $1=$ Hiç, 2 = Bir kez, 3 = İki veya üç kez ve 4 = Üçten çok kez" şeklinde cevaplanmaktadır. Yapılan DFA sonucu Siber Zorbalık Ölçeği'nin uyum indeksleri $\chi^{2}=$ $2.56, \mathrm{sd}=2, \mathrm{p}=.27 ; \chi^{2} / \mathrm{sd}=1.28 ; \mathrm{GFI}=.99, \mathrm{CFI}=.99$, SRMR $=.02, \mathrm{RMSEA}=$ .03 olarak hesaplanmıştır. Siber Mağduriyet Ölçeği'nin uyum indeksleri ise $\chi^{2}=1.36, \mathrm{sd}=2, \mathrm{p}=.50 ; \chi^{2} / \mathrm{sd}=.68 ; \mathrm{GFI}=.99, \mathrm{CFI}=1.00, \mathrm{TLI}=1.00, \mathrm{SRMR}=$ .01 , RMSEA $=.00$ olarak hesaplanmıştır. Çalışmada sonuç olarak 12 maddeden oluşan tek faktörlü bir yapı elde edildiği görülmektedir. Katılımcının puanı siber zorbalık yaptım kısmında 14 veya üzeri ama siber zorbalığa maruz kaldım kısmındaki puan 12 ise sadece siber zorba; katılımcının puanı siber zorbalık yaptım kısmında 12 ama siber zorbalığa maruz kaldım kısmındaki puanı 14 ve üzeri ise sadece siber mağdur; katılımcının puanı hem siber zorbalık yaptım kısmında 14 ve üzeri hem de siber zorbalığa maruz kaldım kısmında 14 ve üzeri ise siber zorba-mağdur; katılımcının puanı hem siber zorbalık yaptım kısmında 12 hem de siber zorbalığa maruz kaldım kısmında 12 ise siber zorba ya da mağdur olmayan olarak gruplama yapılması önerilmektedir (Tanrıkulu, 2015). Mevcut çalışmada siber zorbalık ya da siber mağduriyet puanları bir değişken olarak kullanılmamış, Tanrıkulu'nun önerisi doğrultusunda örneklem grubunu siber zorba ve siber mağdur olup olmama durumlarına göre sınıflandırmak için kullanılmıştır. Ölçeğin Cronbach's Alfa değeri .87 olarak bulunmuştur. 
Siber Zorbalı̆̆a İlişkin Duyarlılık Ölçeği (SZDÖ): Orijinal formu Tanrıulu, Kınay ve Arıcak tarafından 2013 yılında geliştirilmiştir. Yapılan AFA sonucunda ölçeğin tek faktörlü bir yapı gösterdiği görülmüştür. Açıklanan varyans oranı \%46.658 ve Cronbach's Alfa değeri .87 olarak bulunmuştur. Yap1lan DFA sonucunda elde edilen uyum indekslerinden $\chi^{2} / \mathrm{sd}=3.22$, RMSEA= $.08, \mathrm{GFI}=.97, \mathrm{CFI}=.95$ olarak hesaplanmıştır. Sonuç olarak 13 maddeden oluşan tek faktörlü bir yapı elde edildiği görülmektedir. Ölçek "Hiçbir za$\operatorname{man}=1$, Nadiren $=2$, Bazen $=3$, S1klıkla $=4$ ve Her zaman $=5$ " şeklinde puanlanmaktadır. Ölçekten alınan puanın yüksekliği siber zorbalığa ilişkin duyarlılığın yüksek olduğunu göstermektedir (Tanrıkulu vd., 2013). Mevcut çalışmada yapılan analiz sonucunda, KMO değeri 0,95 olarak bulunmuştur. Barlett's Sphericity testi sonucunda elde edilen değerin anlamlı düzeyde olduğu ortaya çıkmıştır $(\chi 2=5954,387 ; p<0.01)$. Açıklanan toplam varyansın \%73,56 olarak gerçekleştiği görülmüştür. Ölçeğin Cronbach's Alfa iç tutarl1lık katsayısı 0.97 dir.

Rosenberg Benlik Değeri Ölçeği (RBDÖ): Orijinal formu Rosenberg (1965) tarafından geliştirilen ölçeğin Çuhadaroğlu (1986) tarafından Türkçe'ye uyarlaması yapılmıştır. Uyarlama çalışmasında aracın güvenirlik katsayısı .71 olarak belirtilmiştir. 5 olumlu 5 olumsuz kodlanmış olmak üzere 10 maddeden oluşan tek faktörlü bir yapı elde edildiği görülmektedir. Ölçek "Hiç katılmıyorum = 1, Katılmıyorum = 2, Kararsızım = 3, Katılıyorum = 4 ve Kesinlikle katılıyorum $=5$ " şeklinde derecelendirilen beşli Likert tipindedir. Ölçeğin uyum indeksleri ise $\chi^{2}=153.57, \mathrm{sd}=61, \mathrm{p}=.50 ; \chi^{2} / \mathrm{sd}=2,51$; GFI $=.90, \mathrm{CFI}=.95, \mathrm{SRMR}=.055, \mathrm{RMSEA}=.057$ olarak hesaplanmıştır. Mevcut çalışmada yapılan analiz sonucunda, KMO değeri 0,81 olarak bulunmuştur. Barlett's Sphericity Testi sonucunda elde edilen değerin anlamlı düzeyde olduğu ortaya çıkmıştır $(\chi 2=2751,863 ; p<0.01)$. Açıklanan toplam varyansın \%45,03 olarak gerçekleştiği görülmüştür. Ölçeğin Cronbach's Alfa iç tutarl1lık katsayısı 0.84 tür.

\section{Verilerin Analizi}

Araştırma kapsamında okul yöneticileri ve öğretmenlerden siber mağdur olanlarda siber zorbalığa ilişkin duyarlılığın özsaygının anlamlı bir yordayıcısı olup olmadığı hiyerarşik çoklu regresyon analizi ile sınanmıştır. Yöntemin araştırmanın veri seti için kullanımının uygun olup olmadığına karar 
vermek amaciyla öncelikle regresyon analizine ilişkin varsayımlar sınanmıştır. Regresyon analizinin varsayımlarından birisi bağımlı ve bağımsız değişkenlerin en az eşit aralık ölçeğinde ölçülen sürekli değişken olmaları ve normal dağılım göstermeleri gerekmektedir (Büyüköztürk, 2011). Yordayan ve yordanan değişkenlerin normal dağlım gösterip göstermediklerini kontrol etmek için ortalama, mod, medyan değerleri ile çarpıklık ve basıklık katsayıları incelenmiştir (Tablo 2).

Tablo 2. Yordayan ve yordanan değişkenlere ilişkin betimsel istatistikler

\begin{tabular}{lll}
\hline & Siber Zorbalığa İlişkin Duyarlılık & Özsayg \\
\hline Ortalama & 4,14 & 4,29 \\
Medyan & 4,33 & 4,40 \\
Mod & 5,00 & 5,00 \\
Çarpıklık Katsayısı &,- 952 &,- 722 \\
Basıklık Katsayısı &, 354 &,- 016 \\
\hline
\end{tabular}

Tablo 2 incelendiğinde ortalama, medyan ve mod birbirlerine yakın değerler aldığı çarpıklık ve basıklık katsayılarının da +1 ve -1 aralığında olduğu görülmektedir. Dolayısıyla dağılımın normalden aşırı sapma göstermediği söylenebilir.

Hiyerarşik çoklu regresyon analizine ilişkin varsayımlardan bir diğeri yordayıcı değişkenle yordanan değişken arasındaki ilişkinin doğrusal olup olmadığının incelenmesidir. Bu varsayımın kontrolü için saçılma diyagramı çizilmiştir. Standardize edilmiş artık değerler ile standardize edilmiş yordanan değerler için oluşturulan saçılma diyagramının doğrusal bir ilişkiyi tanımladığı, normal dağılım eğrilerinin normale yakın bir dağılım gösterdiği görülmüştür.

Hiyerarşik çoklu regresyon analizinin varsayımlarının sınanması adına varyans büyütme faktörleri (VIF) ve tolerans değerleri de incelenmiş, Can'ın (2017) önerdiği gibi VIF değerlerinin 10'dan küçük ve tolerans değerlerinin .2'den büyük olduğu görülmüştür. Ayrıca regresyon işleminde aşırı uç değerler mevcut regresyon denkleminin olması gereken kuramsal modele uyumunu bozduğu için Mahalanobis uzaklıkları hesaplanarak bu değerler incelenmiştir. Araştırmada bağımsız değişken sayısı bir ve p: 0,01 için Mahalanobis uzaklık noktası 6,63'dür (Can, 2017). 6,63'ün üzerinde olan 77 uç değer veriden silinmiştir. Bu verilerin silinmesi ile regresyon analizinin yapılacağı örneklem 352'ye düşmüştür. 352 örneklemden sadece 99'u siber 
mağduriyet yaşadığından regresyon analizi 99 veri dizisi üzerinde yapılmıştir.

\section{Bulgular}

Siber zorbalığa ilişkin duyarlılığın özsaygıyı yordayıcılığını belirlemek için hiyerarşik çoklu regresyon analizi yapılmıştır. Regresyon analizinden önce değişkenlerin ortalamaları, standart sapmaları ve bu değişkenlerin kendi aralarındaki korelasyona bakılmıştır. Daha sonra, yapılan hiyerarşik regresyon analizi ile değişkenler arasındaki doğrudan etki araştırılmıştır. Yapılan ilk analizler sonucunda değişkenlerin birbirleri ile korelasyonu, ortalama ve standart sapma puanları Tablo 3'te sunulmuştur.

Tablo 3. Değişkenlere ilişkin ortalama, standart sapma ve korelasyonlar $(N=99)$

\begin{tabular}{llllll}
\hline & & $\dot{\mathbf{X}}$ & SS & $\mathbf{1}$ & $\mathbf{2}$ \\
\hline $\mathbf{1}$ & Özsayg1 & 4,14 &, 66 & 1 &, $320^{*}$ \\
\hline $\mathbf{2}$ & $\begin{array}{l}\text { Siber Zorbalığa } \\
\text { İlişkin Duyarlılık }\end{array}$ & 4,04 &, 93 & & 1 \\
\hline
\end{tabular}

${ }^{*} \mathrm{p}<0,01$

Tablo 3' de görüldüğ̈̈ gibi, elde edilen verilere göre katılımcıların özsaygı düzeyleri 4,14, siber zorbalığa ilişkin duyarlılık düzeyleri 4,04'dür. Ayrıca siber mağduriyet yaşayan okul yöneticileri ve öğretmenlerin özsaygı düzeyleri ile siber zorbalığa ilişkin duyarlılık düzeyleri arasında orta düzeyde, pozitif ve anlamlı bir ilişki vardır $(r=, 320 p<.01)$.

Siber mağdur okul yöneticileri ve öğretmenlerin siber zorbalığa ilişkin duyarlılıklarının özsaygı düzeylerine etkisini araştırmak amacıyla hiyerarşik çoklu doğrusal regresyon analizi yapılmıştır. Yapılan analizde demografik değişkenlerden yaş, cinsiyet, kıdem ve öğrenim düzeyi kontrol değişkenleri olarak 1. adımda regresyon denklemine eklenmiştir. Analiz bulguları Tablo 4 ' te gösterilmiştir.

Tablo 4. Siber mă̆durlarda siber zorbalı̆̆a ilişkin duyarhlı̆̆ın özsaygıyı yordamasına ilişkin hiyerarşik çoklu regresyon analizi sonuçlan $(N=99)$

\begin{tabular}{|c|c|c|c|c|c|c|c|}
\hline \multirow[t]{2}{*}{ Model } & \multirow[b]{2}{*}{ Yordayıcı Değişkenler } & \multicolumn{6}{|c|}{ Bağımlı Değişken Özsaygı } \\
\hline & & $\mathrm{B}$ & ShB & $\beta$ & $\mathrm{t}$ & $p$ & $\mathrm{R}^{2}$ \\
\hline 1. Adım & (Sabit) & 4,074 & 663 & & 6,145 & 000 & \\
\hline (Enter & Yaş & 078 & 245 & 035 & 317 & ,752 & \\
\hline \multirow[t]{2}{*}{ Metodu) } & Cinsiyet & 042 & ,148 & 031 & 281 & ,779 & \\
\hline & Öğrenim Düzeyi &,- 055 & ,211 &,- 029 &,- 262 & ,794 & \\
\hline
\end{tabular}




\begin{tabular}{|c|c|c|c|c|c|c|}
\hline & Kıdem &,- 034 & ,090 &,- 041 &,- 380 & ,705 \\
\hline \multirow{6}{*}{$\begin{array}{l}\text { 2. Adım } \\
\text { (Enter } \\
\text { Metodu) }\end{array}$} & (Sabit) & 2,676 & 757 & & 3,537 & 001 \\
\hline & Yaş & ,208 & ,236 &, 094 & ,881 & ,381 \\
\hline & Cinsiyet & 005 & 141 & ,004 & 036 & 971 \\
\hline & Öğrenim Düzeyi & 080 & ,205 &, 042 & 391 & 697 \\
\hline & Kidem & 000 & ,087 &, 000 &,- 004 & ,997 \\
\hline & Siber Zorbaliğa İlişkin Duyarlılık & 241 & 072 & $337^{*}$ & 3,333 & ,001 \\
\hline
\end{tabular}

${ }^{*} \mathrm{p}<0,01$

Tablo 4' te görüldüğü gibi yaş, cinsiyet, öğrenim düzeyi ve kıdem değişkenleri kontrol edildikten sonra yapılan hiyerarşik çoklu regresyon analizi sonucunda, siber mağdur okul yöneticileri ve öğretmenlerin siber zorbalığa ilişkin duyarlılıklanı, özsaygı düzeylerini anlamlı bir şekilde yordamaktadır $(\beta=, 337)$. Özsaygıdaki varyansın \%11,1'i bu model tarafından açıklanmaktadır $\left(\mathrm{R}^{2}\right.$ model $\left.=, 111 p<.01\right)$. Demografik değişkenlerin anlamlı bir katkısının olmadığı modeldeki varyansın tamamına yakını siber zorbalığa ilişkin duyarlılık tarafından sağlanmaktadır $\left(\mathrm{R}^{2}\right.$ değişim $\left.=, 108 p<.01\right)$.

\section{Tartışma ve Sonuç}

Yaşadığımız dönemde şiddetin dijitalleşmiş hali olarak karşımıza çıkan siber zorbalık, hedef olarak belirlediği kişi ve kişiler üzerinde mağduriyet yaşatmaktadır. Bu kişilerin yaşadıkları mağduriyette ise duyarlılık önemli bir faktördür. Duyarlılık ayrıca siber zorbalık davranışlarının azalmasında ve mağdurun özsaygını korumasında etkilidir. Çalışma bu doğrultuda okul yöneticileri ve öğretmenlerin siber mağduriyet durumu belirlenmeyi ve bu mağdurların siber zorbalığa ilişkin duyarlılıklarının özsaygıya olan etkisini araştırmayı amaçlamaktadır.

Araştırma sonucunda elde edilen bulgulara göre katılımcıların \% 20,1'inin siber mağdur oldukları görülmektedir. Çalışmada siber mağduriyet yaşayan okul yöneticileri ve öğretmenlerin özsaygı düzeyleri ile siber zorbalığa ilişkin duyarlılık düzeyleri arasında anlamlı bir ilişki bulunmuştur. Literatürdeki çalışmalar siber zorbalığa ilişkin mağduriyetin özsaygiyı büyük oranda etkilediği yönündedir. Örneğin Patchin ve Hinduja'nın (2010, s. 619) yaptıkları çalışmada siber mağduriyet ve siber zorbalık önemli ölçüde daha düşük özsaygı ile ilişkili olduğunu belirtilmektedirler. Bu sonuç, Türkiye'de gençler üzerinde yapılan çalışma da siber zorba ve siber mağdur olma ile benlik saygısının ilişkili olduğunun belirtildiği (Aydın, 2019: 64) 
çalışma ile de uyumludur. Ayrıca Aliyev ve Gengec (2019, s. 161) ile Álvarez-García ve arkadaşları (2020, s. 11) tarafından yapılan çalışmalarda özsaygı ile siber zorbalık arasında negatif ve ters yönlü ilişki olduğu sonucuna ulaşılmıştır. Adiyanti ve arkadaşları (2020, s. 258) ise düşük benlik saygısının duygusal düzenleme kapasitesini azalttığını ve böylece bireyin siber zorbalık eğiliminin arttı̆̆ın belirtmektedirler. Brewer ve Kerslake de (2015, s. 258) özsaygının siber mağduriyetin öncüsü olduğunu ve özsaygısı düşük olan bireylerin daha fazla siber mağduriyet bildirdiklerini ifade etmektedirler. Visinskaite ise $(2015$, s. 32) siber mağduriyet ne kadar sık veya şiddetli olursa mağdurların özsaygılarının da o kadar düşük olacağını belirtmektedir. Ancak bununla beraber düşük özsaygının mağduriyetin sebebi mi yoksa sonucu mu olduğu konusunda bir netlik bulunmamaktadır.

Brack ve Caltabiano $(2014$, s. 8) tarafından yapılan çalışmada siber zorba ve mağdurların özsaygı düzeyleri arasında anlamlı bir fark olmadığı sonucuna varılmıştır. Mevcut çalışmada ise siber mağduriyet yaşayan okul yöneticileri ve öğretmenlerin siber zorbalığa ilişkin duyarlılıklarının özsaygı düzeylerini etkilediği sonucuna varılmıştır. Bir başka ifadeyle önceki dönemlerde siber zorbalığa maruz kalan yönetici ve öğretmenlerin süreci atlattıktan sonra siber zorbalık konusunda duyarlılıklarının geliştiği ve bu duyarlılığın özsaygıyı artırttığı söylenebilir. İlk bakışta elde edilen bu sonucun literatürle uyumlu olmadığı düşünülebilir. Ancak literatürdeki siber mağduriyet ve özsayg ilişkisini inceleyen çalışmaların büyük çoğunluğunun ergenlik ve ilk gençlik dönemindeki ortaokul, lise ve üniversite öğrencileri ile üzerinde yapıldığı görülmektedir. Dolayısıyla bu yaş grubundaki bireyler ile lisans mezunu, çoğunluğunun 11 yıllık mesleki deneyimi olan ve rol model olmayı gerektiren eğitim sektöründe çalışan okul yöneticileri ve öğretmenlerin siber zorbalığın yarattığ mağduriyete karşı tepkileri ve mağduriyetten doğan zararları engelleme düzeyleri arasında farklar vardır.

\section{Öneriler}

Bugün mağdur olanların gelecekte zorba olma potansiyelleri göz önüne alındığında siber zorbalığın yakın gelecekte ne kadar büyük bir tehdit olacağını söylemek yanlış olmayacaktır. Bilgi ve iletişim teknolojilerindeki gelişmeler ve sunduğu farklı uygulamalar ile yakın gelecekte hayatımızda önemli bir yer tutacak olan Web 3.0 ve Web 4.0 teknolojileri ile siber zorba- 
lık tehditlerinin artması da muhtemeldir. Bu nedenle özellikle okul yöneticileri ve öğretmenlerin gelecek teknolojiler ve olası riskleri konularında bilgilendirilmeleri ve siber mağduriyet yaşamadan duyarlılıklarının arttırılması gerekmektedir.

Ayrıca farklı yaş ve meslek grubundaki kişilerle siber zorbalık ve mağduriyete ilişkin duyarlılığın özsaygıyla olan ilişkisini inceleyen çalışmalar yapılmalıdır. Ayrıca bu çalışmalarda siber mağduriyetin öncesindeki ve sonrasındaki özsaygı düzeylerinin ve hangi siber zorbalık davranışın daha fazla mağduriyet yarattı̆̆ını belirlenmesine yönelik çalışmalarla ilgili literatürü zenginleştirmesi gerekmektedir.

Özellikle içinde bulunduğumuz küresel pandemi döneminde birçok insan evden çalışmaya, okulların da uzaktan eğitime geçmesiyle birlikte yönetici, öğretmen ya da öğrenci olmak üzere birçok kişi bilgisayar ve telefonla çok daha fazla vakit geçirmeye başlamıştır. Bu durum özellikle kişisel iletişim bilgilerini daha fazla paylaşmak durumunda kalan eğitimciler başta olmak üzere tüm toplum için risk oluşturmaktadır. Bu dönemde muhtemel siber zorbalık ve mağduriyette artışların olmaması için bireylerin siber zorbalığa ilişkin duyarlılıklarını arttırmaları gerekmektedir. 


\section{EXTENDED ABSTRACT}

\section{The Effect of Cyber Victimization and Cyberbullying Sensitivity on Self-Esteem in Work Life

\author{
Çiğdem Çakır - Esra G. Kaygısız \\ Kadriye Abdülmecit Özgözen Secondary School, Giresun University
}

The Internet offers individuals uncontrolled, uninterrupted and free communication environments and virtualizes many aspects of life. These communication environments, which are diversified and changing day by day, carry the physical and psychological violence elements to the virtual environment. This process, also known as cyberbullying, electronic bullying, cyber harassment, online violence or digital violence, is one of the biggest negativities brought by the internet. Therefore, cyberbullying can be defined as the form of other bullying and violent behaviors done with electronic devices and software. In other words, it has emerged with the spread of technology and is the digital form of bullying. Cyberbullying allows the perpetrator tobully $24 / 7$ and 365 days a year using information and communication technologies. Cyberbullying is a phenomenon that threatens individuals of all ages and characteristics in daily life, business and education life. Therefore, it can be considered as the new form of bullying of the 21st century. Cyberbullying is a type of violence that allows the bully to display bullying behaviors against the victim in any place, time and place and as often as they want. In addition, it causes the contents, that are disturbing, humiliating, hurtful, harassing, etc. for the victim, to be seen, copied, stored and shared again after years by millions of people around the world in seconds. Bully performs all these actions using mobile phones, tablets and computers over the Internet, through websites, blogs, social media applications, games, forums, and e-mail accounts. Cyberbullying, on the other hand, creates cyber victimization. Cyber victimization is the exposure to cyberbullying and the loss of an individual financially or 
morally from these behaviors. Cyberbullying primarily affects the victim negatively. In some cases, besides the victim, it also affects the family, immediate environment or the institution they work for, financially or morally. In addition, this situation has different negative effects on the victims. In this study, the effect of cyber victimization on individuals' selfesteem is investigated.

With the widespread use of information and communication technologies, teachers are frequently called by parents outside of working hours by phone, social media channels or online messaging programs. This situation disrupts the work-private life balance of teachers and causes unauthorized sharing of their contact information, personal numbers and social media account information. Therefore, the risk of teachers being victimized by students, parents and colleagues is higher than other sectors. In addition, the responsibilities of teachers towards their students require them to be highly sensitive to cyberbullying and cyber victimization. From this point of view, the present study aims to determine the cyber victimization and cyberbullying sensitivity levels of teachers and administrators working in primary and secondary schools. Also the effect of their sensitivity levels on their self-esteem levels.

Relational scanning model was used in the research. The relationship between the level of sensitivity and self-esteem regarding cyberbullying was tried to be determined by scales applied to administrators and teachers working in public primary and secondary schools. In this context; (i) cyber victimization status of the sample group was determined, (ii) the effect of cyber-bullying sensitivity on self-esteem was examined in cyber victims. The sample of the study consists of school administrators and teachers that are working at official schools that are affiliated to the Ministry of National Education at Gaziantep province, Şahinbey district. In order to collect data, Personal Information Form, Revised Cyber Bullying Inventory, Cyberbullying Sensitivity Scale and Rosenberg Self-Esteem Scale were used. Descriptive statistics and hierarchical multiple regression analysis were used to analyse the data. Assumptions about regression analysis were tested to determine whether the method is suitable for use in the data set of the study. The data set was found to be suitable for regression analysis. In the planning phase of the study, it was thought to investigate the relationship between self-esteem and cyber-bullying sensiti- 
vity in cyberbullies and cyber victims. However, after preliminary analysis to test whether the data set is suitable for regression analysis, the number of cyberbully in the data set that will be put into analysis is three and this number is not sufficient for regression analysis. Because, as a general rule for regression analysis, 5 times the number of independent variables is recommended. From this point of view, the relationship between selfesteem cyber-bullying sensitivity was researched only on teachers and administrators who experienced cyber victimization (99).

According to the data obtained, the self-esteem level of the participants is 4.14 and their sensitivity level towards cyber bullying is 4.04 . In addition, there is a moderate, positive and significant relationship between the self-esteem levels of cyber-victim school administrators and teachers and their cyberbullying sensitivity $(r=, 320 \mathrm{p}<.01)$. As a result of the hierarchical multiple regression analysis performed after controlling for age, gender, education level and seniority variables, cyber-victim school administrators and teachers' cyberbullying sensitivity levels predicted their selfesteem levels significantly $(\beta=, 337) .11 .1 \%$ of the variance in self-esteem is explained by this model $(\mathrm{R} 2$ model $=, 111 \mathrm{p}<.01)$. Almost all of the variance in the model, where demographic variables do not make a significant contribution, is provided by the cyber bullying sensitivity (R2 change =, $108 \mathrm{p}<.01)$.

\section{Kaynakça / References}

Aliyev, R. ve Gengec, H. (2019). The effects of resilience and cyberbullying on selfesteem. Journal of Education, 199(3), 155-165.

Arıcak, O. T., Tanrıkulu, T. ve Kınay, H. (2012). Siber mağduriyet ölçeğinin ilk psikometrik bulguları. Akdeniz Eğitim Araştırmaları Dergisi, 11, 1-6.

Aslan, A. ve Doğan, B.Ö. (2017). Çevrimiçi şiddet: Bir siber zorbalık alanı olarak “Potinss" örneği. Marmara İletişim Dergisi, 27, 95-119. DOI: 10.17829/midr.20172729524

Aydın, M. (2019). Siber zorbalkla karşlaşan gençlerin benlik saygısı ve stresle baş etme yöntemlerinin incelenmesi. Yayınlanmamıs yüksek lisans tezi, T. C. Maltepe Üniversitesi, Psikoloji Anabilim Dalı, İstanbul.

Baştak, G. ve Altınova, H. H. (2015). Lise öğrencilerinde yaratıc drama yöntemiyle siber zorbalık hakkında duyarlılık oluşturma. Yaratıcı Drama Dergisi, 10(1), 91-102. DOI: 10.21612/yader.2015.009. 
Baştürk Akca, E. ve Sayımer, İ. (2017). Siber zorbalık kavramı, türleri ve ilişkili olduğu faktörler: Mevcut araştırmalar üzerinden bir değerlendirme. Online Academic Journal of Information Technolog, 8(30). DOI: 10.5824/1309-1581.2017.5.001.x

Bayezid, G. (2000). Bastırma Duyarlılık Ölçeği'ni Türk kültürüne uyarlama çalışması. Düşünen Adam, 13(2), 99-106.

Brack, K. ve Caltabiano, N. (2014). Cyberbullying and self-esteem in Australian adults. Journal of Psychosocial Research on Cyberspace, 8(2), article 7. DOI: 10.5817/CP2014-2-7.

Brewer, G. ve Kerslake, J. (2015). Cyberbullying, self-esteem, empathy and loneliness. Computers in Human Behavior, 48(2015), 255-260. http://dx.doi.org/10.1016/j.chb.2015.01.073 0747-5632

Bridge, E. D. ve Duman, N. (2019). Ergenlerde siber zorbalığa duyarlılığın demografik değişkenler açısından incelenmesi. Kıbrıs Türk Psikiyatri ve Psikoloji Dergisi, 1(3), 158-165 DOI:10.35365/ctjpp.19.1.20

Büyüköztürk, Ş. (2011). Sosyal bilimler için veri analizi el kitabı. 13. Baskı, Ankara: Pegem Akademi Yayınevi.

Campfield, D.C. (2008). Cyber bullying and victimization: psychosocial characteristics of bullies, victims, and bully/victims. Yayınlanmamış doktora tezi). The University of Montana, Montana.

Can, A. (2017). SPSS ile bilimsel araştırma sürecinde nicel veri analizi. 5. Bask1, Ankara: Pegem Akademi Yayınevi.

Cebecioğlu, G. ve Altıparmak, İ. B. (2017). Dijital şiddet: Sosyal paylaşım ağları üzerine bir araştırma. Sakarya University Journal of Education, 7(2), 423-43.

Charoenwanit, S. (2019). The relationship of cyber-bullying and academic achievement, general health, and depression in adolescents in Thailand Walailak. J Sci E Tech, 16(4), 231-241.

Çiftçi, H. (2018). Öğrencilerin siber mağduriyet düzeylerinin karşılaştırılması. Gümüşhane Üniversitesi İletişim Fakültesi Elektronik Dergisi, 6(2), 1536-1567.

Çuhadaroğlu, F. (1985). Adolesanlarda benlik saygısı. Yayınlanmamış uzmanlık tezi). Hacettepe Üniversitesi, Ankara.

Demirtaş, Ö. ve Karaca, M. (2018). Siber mobbing: Kavramsal çerçeve, öncülleri ve sonuçları. International Journal Entrepreneurship and Management Inquiries, 2(2), 20-34.

Doğan, A., Özgün, O. H., Demir, R. ve Türkmen, E. (2016). Kariyer danışmanlığı ve özsaygı arasındaki ilişkinin incelenmesi. Uluslararası Sosyal Araştırmalar Dergisi, 9(47). 
Erdur-Baker, Ö. ve Kavsut, F. (2010). Cyberbullying and its correlation to traditional bullying, gender and frequent and risky usage of internet-mediated communication tools. New Media $\mathcal{E}$ Society, 12(1), 109-125. DOI:10.1177/1461444809341260

Farley, S., Coyne, I., Sprigg, C., Axtell, C. ve Subramanian, G. (2015). Exploring the impact of workplace cyberbullying on trainee doctors. Medical Educatıon, 49, 436-443.

Furnham, A. (2008). The self-esteem industry. In: Head \& Heart Management. Palgrave Macmillan, London. https://doi.org/10.1057/9780230598317_81

Healy, F. (2013). Cyber bullying and its relationship with self esteem and quality of frendships amongst adolescent females in Ireland (Submitted in partial fulfilment of the requirements of the Higher Diploma) Dublin Business School, Arts and Psychology, Dublin.

Kaygisız, E. G. (2020). Şiddetin e-hali: Siber zorbalık. Türkiye Insan Hakları ve Eşitlik Kurumu Akademik Dergisi Şiddetin Önlenmesi Çalıştayı Özel Sayısı, Mart, 2020.

Lumsden, K. ve Harmer, E. (2019). Online othering exploring digital violence and discrimination on the web. Palgrave Macmillan, Switzerland. https://doi.org/10.1007/978-3-030-12633-9.

Makri-Botsari, E. ve Karagianni, G. (2014). Cyberbullying in Greek adolescents: The role of parents. Procedia-Social and Behavioral Sciences. 116, 3241-3253.

Özdamar, K. (2003). Modern bilimsel araştırma yöntemleri. Eskişehir: Kaan Kitabevi.

Özkan, İ. (1994). Benlik saygısını etkileyen etkenler. Düşünen Adam, 7(3), 4-9.

Özmen, Ş. Y. (2018). Dijital şiddet, siber zorbalık ve yeni medya okuryazarlığı üzerine bir değerlendirme. Uluslararası Sosyal Araştırmalar Dergisi, 11(61). http://dx.doi.org/10.17719/jisr.2018.2989

Patchin, J. W. ve Hinduja, S. (2010). Cyberbullying and self-esteem. Journal of School Health, 80(12), 614-621.

Pekşen Süslü, D. (2016). Lise öğrencilerinde siber zorbahı ve siber mağduriyetin benlik saygsl, anne, baba ve akran ilişkileri açısından incelenmesi. Yayınlanmamış doktora tezi). Maltepe Üniversitesi, Sosyal Bilimler Enstitüsü, İstanbul.

Reisoğlu, İ., Gedik, N. ve Göktas, Y. (2013). Öğretmen adaylarının özsaygı ve duygusal zekâ düzeylerinin problemli internet kullanımıyla ilişkisi. Eğitim ve Bilim, 38(170).

Rosenberg, M. (1965). Society and the adolescent self-image. Princeton, NJ: Princeton University Press. 
Rosenberg, M., Schooler, C., Schoenbach, C. ve Rosenberg, F. (1995). Global selfesteem and specific self-esteem: Different concepts, different outcomes. American Sociological Review, 60(1), 141-156. https://www.jstor.org/stable/2096350

Smith, P., Mahdavi, J., Carvalho, M., Fisher, S., Russell, S. ve Tippett, N. (2008). Cyberbullying: Its nature and impact in secondary school pupils. Journal of Child Psychology and Psychiatry, 49, 376-385. http://dx.doi.org/10.1111/j.14697610.2007.01846.x

Şahin, M. (2012). The relationship between the cyberbullying/cybervictmization and loneliness among adolescents. Children and Youth Services Review, 34(2012), 834-837.

Şahin Baltacı, H. ve Altan, T. (2016). Lise öğrencilerinde benlik saygısının yordayıcısı olarak depresyon, bağlanma ve şiddet eğilimi. Mehmet Akif Ersoy Üniversitesi Eğitim Fakültesi Dergisi, 40, 227-239. DOI: 10.21764/efd.34257

Tanrikulu, İ. (2015). The relationships between cyber bullying perpetration motives and personality traits: Testing uses and gratifications theory (Yayımlanmamış doktora tezi). Orta Doğu Teknik Üniversitesi, Eğitim Bilimleri Enstitüsü, Ankara.

Tanrıkulu, T., Kınay, H. ve Arıcak, O. T. (2013). Siber zorbalığa ilişkin duyarlılık ölçeği: Geçerlik ve güvenirlik çalışması. Trakya Üniversitesi Ĕ̆itim Fakültesi Dergisi, $3(1), 38-47$.

Taştekin, E. (2016). Ergenlerin arkadaşlk ilişkileri ve benlik saygısı ile siber zorbalk ve siber mağduriyet arasındaki ilişkiler.Yayınlanmamış yüksek lisans tezi. Hacettepe Üniversitesi, Sağlık Bilimleri Enstitüsü, Ankara.

Topcu, Ç. ve Erdur-Baker, Ö. (2010). The revised cyber bullying inventory (RCBI): Validity and reliability studies. Procedia Social and Behavioral Sciences, 5, 660664. DOI: 10.1016/j.sbspro.2010.07.161

Uğur, U., Sarığlu Uğur, S. ve Soba, M. (2019). Tüketicilerin özsaygı algılamaları ve otomobil tercihleri arasındaki ilişki: Bir araştırma. İşletme Araşstrmaları Dergisi, $11(4), 2762-2771$.

Visinskaite, V. (2015). Workplace bullying: In relation to self-esteem, stress, life satisfaction and cyberbullying. Yayınlanmamış yüksek lisans tezi. Dublin Business School, School of Arts, Dublin.

Yllmaz, A. S. (2011). Üniversite öğrencilerinin karar vermede özsaygı ve karar verme stillerinin benlik saygısı ve utangaçlık açısından incelenmesi. Yayımlanmamış yüksek lisans tezi. Selçuk Üniversitesi, Eğitim Bilimler Enstitüsü, Konya.

Tavşancıl, E. (2010). Tutumları ölçülmesi ve SPSS ile veri analizi. Ankara: Nobel Yayın Dağtım. 
Tezbaşaran, A. A. (1997). Likert tipi ölçek geliştirme kılavuzu. Ankara: Türk Psikologlar Derneği.

Trompenaars, F. ve Voerman, E. (2009). Servant-leadership across cultures: Harnessing the strengths of the world's most powerful management philosophy. New York: The McGraw-Hill Companies.

Vinod, S. ve Sudhakar, B. (2011). Servant leadership: A unique art of leadership, Interdisciplinary Journal of Contemporary Research in Business, 2(11), 456-467.

Yilmaz, V. ve Çelik, H. E. (2009). Lisrel ile Yapısal Eşitlik Modellemesi I temel kavramlar, uygulamalar, programlama. Ankara: Pegem Akademi Yayıncilı.

\section{Kaynakça Bilgisi / Citation Information}

Çakır, Ç. ve Kaygısız, E. G. (2020). Çalışma yaşamında siber mağduriyet ve siber zorbalığa ilişkin duyarlılı̆̆ın özsaygıya etkisi. OPUSUluslararası Toplum Araştırmaları Dergisi, 16(30), 2505-2527. DOI: 10.26466/opus.724131 